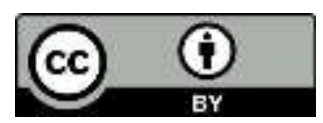

\title{
A REPRESENTAÇ̃̃O DO FEMININO NA MÍDIA PENTECOSTAL: UMA ANÁLISE DE DISCURSO DO QUADRO ABRINDO O CORAÇÃO
} The representation of the feminine in the Pentecostal media: A Discourse analysis of the TV
segment Opening your heart

RESUMO: A proposta deste trabalho tem como objeto de estudo o quadro Abrindo o Coração (AC), que é um dos destaques dentro do programa Show da Fé, veiculado pela Rede Internacional de Televisão (RIT), apresentado pelo líder religioso, Missionário R.R. Soares. Trata-se de uma análise da mídia pentecostal com o objetivo de verificar a representação da mulher transmitida por este grupo religioso. Como metodologia, escolhemos duas cartas do quadro Abrindo o Coração, lidas ao vivo no programa Show da fé, e por meio da transcrição deste material usaremos os procedimentos teórico-metodológicas da Análise do Discurso (AD) para compreender de que forma essas mulheres são representadas. O trabalho busca mostrar que o discurso religioso midiatizado interfere de maneira muito pontual nas relações de dominação entre os sexos e constitui um corpo de análise fundamental para os estudos de gênero.

Palavras-chave: Mídia Evangélica; Pentecostais; Gênero; Análise de Discurso.

ABSTRACT: The purpose of this work is to study the object the segment "Opening your heart" $(\mathrm{OH})$, one of the highlights of religious TV program Show of Faith, run by the International Television Network (ITN), presented by its religious leader, missionary R.R.Soares. This is an analysis of the Pentecostal media with the objective of verifying the representation of women transmitted by this religious group. As methodology, I chose two letters from the segment Opening your Heart, read live on the show, and through the transcription of this material we will use the theoretical and methodological procedures of Discourse Analysis (AD) to understand how these women are represented. The work aims at showing that the mediatized religious speech interferes very timely manner the relations of domination between the sexes, and constitutes a body of fundamental analysis for gender studies.

Key-words: Evangelical Media; Pentecostals; Gender; Discourse Analysis. 


\section{Introdução}

A proposta busca trazer esta reflexão sobre gênero e religião para o campo da comunicação por meio do seguinte objeto: o discurso religioso televisivo construído pelo líder da Igreja Internacional da Graça de Deus (IIGD) em seus programas televisivos.

Essa igreja recebeu a classificação de neopentecostal por pregar a crença de que "o cristão deve ser próspero, saudável, feliz e vitorioso em seus empreendimentos terrenos, e por rejeitar usos e costumes de santidade pentecostais, tradicionais símbolos de conversão e pertencimento ao pentecostalismo" (MARIANO, 2004, p.124).

Como a IIGD, podemos citar a Renascer, Universal do Reino de Deus e Mundial do Poder de Deus. Essas igrejas começaram a surgir na segunda metade da década de 1970, trazendo figuras de líderes carismáticos. A prática adquirida por esse novo grupo de religiosos rompe com os antigos padrões de pregação, que davam ênfase ao pentecostalismo dito histórico - grupo que antecede os chamados neopentecostais e que possuem outro foco na sua pregação. O processo de mudança nessa área do discurso ainda continua, dada a necessidade de se manter em evidência, de modo a suprir as necessidades da nossa sociedade pós-moderna, por meio de um discurso que esteja em sintonia com as demandas econômicas, sociais e políticas.

Para continuar a crescer, as igrejas neopentecostais buscam conquistar cada vez mais "adeptos" e usam as mídias - televisão, rádio, jornais, revistas e internet - para atingir esse objetivo, com destaque para a televisão (CUNHA et al, 2008, p.6). São vários os veículos que fazem parte do império midiático do líder da IIGD Romildo Ribeiro Soares, que se apresenta como missionário R. R. Soares, do qual falaremos mais à frente. Nesse contexto, o programa Show da Fé, que é o carro chefe da emissora, representa um marco simbólico não só para a IIGD, como também para os evangélicos de forma geral espalhados pelo Brasil.

Segundo Moraes (2010, p.138), o missionário R. R. Soares é o televangelista mais antigo em atividade no país. Há mais de trinta anos, desde o primeiro programa sob sua liderança, com horário adquirido na Tupi, em 1977, ele tornou seu rosto familiar para a população brasileira. Sempre foi obcecado por televisão e sonhou em usar este veículo para propagar sua crença religiosa. Nos anos 80 , ele amargou horários ruins na grade, mas na década de 90, passou a investir pesado para emplacar de vez em horário 
nobre. Com a aquisição da Rede Internacional de Televisão (RIT), seu império midiático ganhou força, expressão e o reconhecimento dos evangélicos por ser eminentemente de cunho religioso. Soares deixa claro que a RIT nasceu para ser a televisão destinada à família, cultivando valores caros ao grupo religioso ao qual pertence.

O missionário diz acreditar que o poder da mídia é tão grande que pode influenciar tanto para o bem quanto para o mal. Crítico ferrenho do conteúdo veiculado por mídias secularizadas, Soares acredita que um conglomerado midiático, desde que com valores cristãos bem solidificados, pode mudar radicalmente não só a vida das pessoas, do ponto de vista individual, mas também mudar uma nação inteira.

Sabe-se, hoje, que as pesquisas sobre religião no meio acadêmico encontram-se em plena expansão, devido ao potencial crescimento que a religião protestante vem ganhando nas últimas décadas; em especial as igrejas pentecostais e, mais especificamente, as igrejas denominadas como eletrônicas ou midiáticas, fator que mudou e continua mudando de forma exponencial o cenário religioso.

Quem nos traz um dado relevante sobre os estudos de mídia e religião é a pesquisadora Priscila Souza (2012, p.2). Em seu trabalho, ela discute a proposta de pesquisa histórica sobre mídia e religião, apresenta e analisa dados sobre as pesquisas existentes no Banco de Teses e Dissertações da Capes dos anos 1990 a 2010.

O ano de 1994 inaugurou o campo de pesquisas em mídia e religião no Brasil, conforme os dados do Banco de Teses e Dissertações da Capes. As duas primeiras pesquisas foram abrigadas por programas de pós-graduação em Comunicação e em Sociologia, respectivamente, na Universidade Federal do Rio de Janeiro - UFRJ e na Universidade Federal do Ceará - UFCE. Uma delas focava as transformações religiosas a partir das tecnologias da comunicação em grupos evangélicos pentecostais e a outra discutia religião no contexto pós-secular a partir da Renovação Carismática. Até os dias atuais, esses são os dois principais grupos motivadores de pesquisas sobre as relações entre mídia e religião no país. Tema que prosseguiu atraindo pesquisadores durante a década de 1990, que fechou com 11 trabalhos defendidos e estourou na primeira década do século XXI: até 2010, o banco da Capes registra 78 teses e dissertações que apresentam as palavras "religião" e "mídia" no assunto.

Para se ter um parâmetro da importância que o programa tem na mídia televisiva, vejamos a pesquisa feita dia 2 agosto de 2012, segundo informações do site 
especializado em TV, Na Telinha, do portal $\mathrm{UOL}^{1}$. Este site também mostra que o programa Show da Fé ficou atrás apenas dos jornais Brasil Urgente e Jornal da Band, da Copa Sul-Americana e do Agora é Tarde. O Programa Show da Fé alcança quinto lugar de audiência. Aqui também interessa destacar que o programa ficou com média de dois pontos do ibope, que, na região metropolitana de SP significa duas vezes 183.520 pessoas e 58.235 lares (medição de um ponto do Ibope em 2011):

Até então considerado como pivô da baixa audiência da Band no horário nobre e de inibir que a emissora alcançasse índices maiores, o "Show da Fé" ocupou, nesta última quarta-feira (01), o posto de quinta maior audiência do dia. $\mathrm{O}$ show religioso de RR Soares registrou média de 2 pontos no Ibope. O "Brasil Urgente" e "Jornal da Band", ambos com 5 pontos, a Copa SulAmericana, com 4, e o "Agora é Tarde", com 3, foram as únicas atrações com índices superiores. O "Show da Fé" bateu atrações enlatadas, como as séries "Drake \& Josh" e "Kenan \& Kel" ambos com 1 ponto cada, como também venceu os nacionais "Jornal da Noite" e "Claquete" - também com 1 ponto cada. Houve empate com o "Jogo Aberto", "Band Kids", "Os Donos da Bola" e o "Muito+", que também renderam 2 pontos de média. Esses índices são consolidados e são baseados na preferência de um grupo de telespectadores da Grande São Paulo.

Em 2010, o custo para manter o programa Show da Fé sendo vinculado em horário nobre pela Band era de $\mathrm{R} \$ 4$ milhões de reais mensais, hoje, segundo dados recentes divulgados pela Uol Notícias, no dia 19 março de $2013^{2}$, para renovar contrato, a Band pede como pagamento a quantia de R 10 milhões de reais. Significa dizer que o valor pago pelo horário foi inflacionado em 100\%, desde então, como indica, um trecho da matéria:

Pelo sexto ano consecutivo, a Band usa a mesma estratégia para tirar mais dinheiro do pastor R.R.Soares, para renovar o contrato de venda de horário de programação. O líder da Igreja Internacional da Graça já paga hoje cerca de $\mathrm{R} \$ 8$ milhões para ter 60 minutos em horário nobre diariamente. Segundo Ooops!

\footnotetext{
${ }^{1}$ Informações retiradas do site natelinha, com a notícia: "Show da Fé", de R.R. Soares, é a quinta maior audiência da Band, dia 2 agosto 2012.

${ }^{2}$ Informações retiradas do site Uol Notícias, feita pelo colunista Ricardo Feltrin, dia 19/03/2013, às13h13, matéria: Para renovar com pastor, Band quer mais de R\$ 10 milhões por mês.
} 
apurou, a emissora quer subir esse valor agora para pelo menos $\mathrm{R} \$ 10$ milhões.

Numa breve observação sobre a estrutura midiática da IIGD identificamos que a instituição busca exaltar o nome Show da Fé em todos os seus produtos. A Revista Graça/Show da Fé agregou o nome do programa de TV, bem como o jornal impresso, Jornal Show da Fé. A expressão remete à ideia de que a IIGD é um "show de fé". Moraes (2010) diz que "Soares não é muito criativo nos nomes de suas mídias, mas isso pode também ser encarado como uma estratégia midiática para reforçar no mercado o nome, a marca" (MORAES, 2010, p.17).

A mesma observação podemos fazer para os nomes empregados nas instituições como Shopping do Povo e Faculdade do Povo, uma forma de trabalhar e servir ao povo, se apropriando e construindo um significado de proximidade aos menos favorecidos. A partir dessa observação, percebe-se uma tentativa em articular a estrutura midiática em torno de uma marca que represente a identidade da instituição, mostrando assim que as práticas da instituição evangélica têm características pensadas e geradas para e pelo campo das mídias, para a comunicação de massa, lembrando, segundo Cunha (2007) que a cultura das mídias é parte do mercado e trabalha para produzir em expansão, acompanhando o crescimento do mercado, "os produtos da mídia são [A Revista Graça/Show da Fé, Jornal Show da Fé] a mercadoria que é oferecida com o objetivo de fornecer lucro aos grandes empresários da comunicação, daí a necessidade de grande audiência e de ser eco das aspirações do público" (IDEM, 2007, p.20).

Há nas igrejas eletrônicas o interesse em manter o fiel sempre em sintonia com as programações da igreja e principalmente fazê-lo sentir-se, apesar da distância física do templo, participante da congregação, vivenciando a fé por meio de vários formatos e linguagens.

A maioria dos programas é de pregação, com quadros de aconselhamento, testemunho (onde fiéis relatam seus sofrimentos e ganhos após tornar-se fiel de determinada igreja). A inclusão da voz do "outro" é uma estratégia de captura de novos fiéis que poderão se identificar com aquela história ali relatada e passar a acessar a programação da igreja e/ou frequentá-la. Além disso, são divulgadas as ações da igreja pelo Brasil e pelo mundo com agenda de encontros, eventos, etc. Essa prática obriga as igrejas a se estruturarem como mídias também, ou seja, devem ter um amplo rol de profissionais do 
campo da comunicação e ter um planejamento na área (BORELLI, 2011, on-line).

As instituições religiosas são as que têm feito experimentações no sentido de midiatizar-se mais, como já foi falado acima, através do diálogo entre as mídias, do uso de estratégias midiáticas para atingir os seus públicos e do desenvolvimento de ações que buscam prolongar o contato com os seus fiéis para ampliar o sentido de pertencimento.

\section{Seção Abrindo o Coração}

A leitura de uma carta na seção Abrindo o Coração tem no máximo trinta segundos, e a resposta do missionário depende muito do conteúdo dela, não passando de um minuto, em média. São recebidas por volta de 60 a 100 cartas por mês que vem de diversas partes do Brasil, e pela análise geográfica se observa que a maior demanda parte do nordeste.

A partir de 2003, quando o programa passou a ser exibido na Rede Bandeirantes de Televisão este número aumentou, mas ultimamente tem sido menor. As cartas vêm pelo correio e o endereço de correspondência é direcionado para a igrejasede no Estado do Rio de Janeiro, bairro Madureira. As cartas são encaminhadas para o departamento de revisão, organizado por um grupo de colaboradoras. Lá elas fazem uma pré-seleção. Esta pré-seleção diz respeito somente a ter uma letra passível de ser lida, bem como em boas condições de conservação. Dessa forma, as cartas são encaminhadas por malote interno para o departamento de revisão da igreja, cuja sede fica em São Paulo, na Av: São João, 791, lugar onde são gravados os programas Show da Fé, posteriormente levados ao ar ao vivo.

Em São Paulo, as cartas são direcionadas aos revisores que separam por conteúdo. As cartas trazem as mais diversas histórias relacionadas à vida cotidiana ou a questões ligadas ao casamento, aos filhos, à questão financeira, doenças; enfim, às necessidades e inquietações do ser humano. Esta seleção também privilegia os pedidos de oração e a exposição dos problemas. Não é momento para contar as bênçãos ou agradecer por algum milagre, cartas com este teor aparecem, mas são em menor número, uma vez que os telespectadores já conhecem a dinâmica do quadro. Para este fim o quadro Novela da Vida Real é mais indicado. Nestes casos, estas cartas são 
encaminhadas à produção do programa que entra em contato com a pessoa para uma possível gravação.

Todas as cartas são devidamente arquivadas como garantia do programa, para o caso de futuramente algum autor se sentir lesado ou arrependido de ter a sua história lida ao vivo. A produção do programa garante que isso não ocorreu até a presente data, de qualquer forma, isso já é uma regra.

O conteúdo das cartas traz a história de vida de pessoas que sentem a necessidade latente de receber orações e pedir conselhos. Nem todos os que participam deste quadro são necessariamente evangélicos, alguns são simplesmente admiradores do programa e do representante da igreja, R. R. Soares. Inclusive, os participantes fazem questão de dizer isso. Iniciam suas histórias dizendo se são ou não evangélicos, se frequentam a IIGD, ou outra denominação religiosa. E quando são patrocinadoras do programa fazem questão de enfatizar. Inclusive, em algumas cartas, as pessoas cobram as bênçãos, pois se sentem no direito de recebê-las, uma vez que colaboram financeiramente.

As cartas passam então pelo processo de revisão e edição. Neste sentido, é de total responsabilidade dos revisores reescrever a história com no máximo 1000 caracteres, em média, 30 segundos de leitura, desde que a questão central do problema não seja alterada, a fim de serem respondidas de forma pontual pelo missionário.

As cartas são, na sua maioria, muito longas, de duas a três páginas. Observa-se um diálogo muito íntimo, ou seja, as pessoas escrevem como se estivessem face a face com um amigo próximo, em quem confiam. Percebe-se no decorrer da leitura uma necessidade real de serem ouvidas, uma urgência para resolver os problemas e sanar as dúvidas. É como um confessionário, com a diferença que o Brasil todo ouve, apesar do anonimato.

As cartas são então gravadas pela equipe que compõe o programa Show da Fé. A leitura das cartas faz toda a diferença. Uma leitura cheia de emoção traz a sensação de que esta história também pode ser do telespectador, há nitidamente uma participação ativa do público participante do programa no término das gravações, as pessoas se expressam com risos ou mesmo comentários que muitas vezes escapam à edição do programa. Já ocorreu de mulheres escreverem para o programa relatando o desejo de encontrar um companheiro evangélico. Elas explicitam suas características físicas, 
contam suas histórias e idealizam um homem, que na concepção delas, seria ideal. Esta carta é ouvida por um homem que sente o mesmo desejo, e tudo parece tão perfeito que ele entra em contato com a produção do programa para pedir o contato desta mulher. A produção resgata esta carta, liga para a mulher e pergunta se ela quer ou não conhecer um possível pretendente. Recebendo uma resposta positiva, a produção repassa o contato ao pretendente. O fim dessas histórias fica por conta da imaginação ou "da vontade de Deus".

É importante registrar que é sempre mantido o anonimato de todas as pessoas remetentes, bem como sua localidade.

\section{Perfil das remetentes}

Um aspecto interessante e que salta aos olhos assim que nos deparamos com este material é que em quase $95 \%$ dos casos a maioria das remetentes são mulheres. Este dado pode ser facilmente identificado na gravação dos programas, embora haja por parte da produção um esforço considerável para balancear esta disparidade.

A faixa etária varia de acordo com os pedidos e as solicitações, ou seja, mulheres mais velhas escrevem pedindo pelos filhos ou por saúde. Já as mulheres mais novas pedem por casamento/relacionamento ou vida financeira. As cartas demonstram com clareza a identidade de cada uma, pois são escritas com muitos detalhes, como idade, religião, onde moram, com quem moram, há quanto tempo, se frequentam igreja, de qual denominação, se são patrocinadoras, quantos filhos têm, falam da vida financeira e, às vezes, até quanto ganham.

Já as cartas escritas por homens são mais curtas e sucintas. Eles são objetivos e os pedidos ou apelos estão quase sempre relacionados ao trabalho ou à vida sexual. É interessante notar que boa parte é detento, se converteram ao cristianismo na penitenciária e, por terem acesso aos programas televisionados, sentem o desejo de escrever e compartilhar. As cartas vêm de várias regiões do Brasil, notando-se uma maior demanda do estado de Minas Gerais, e também da região do nordeste, mais especificamente dos estados do Piauí e Bahia. A classe social pode ser também observada pelo público que frequenta a IIGD. São pessoas de classe C,D,E. A dificuldade com a escrita e com a norma culta da língua portuguesa também são indícios de pouca escolaridade. 
De forma geral, este é o perfil das mulheres autoras das cartas, responsáveis por constituírem a maioria dos adeptos da igreja. Nosso esforço agora é reconhecer o que, de fato, elas são; o que pensam que são, ou o que dizem que elas são.

\section{Importantes conceitos da Análise de Discurso}

Propusemos para este trabalho a análise do corpus com o respaldo dos procedimentos teórico-metodológicas da Análise do Discurso (AD), registraremos nossa compreensão quanto aos conceitos de condição de produção do discurso, de formação discursiva e de formação ideológica, considerados fundamentais para o estudo da linguagem e, por conseguinte, para o estudo do discurso que constrói uma representação da mulher no programa Show da Fé.

\section{Condições de Produção do Discurso}

As condições de produção do discurso compreendem os sujeitos, a situação e também a memória. Considerando as condições de produção em sentido estrito temos as circunstâncias da enunciação: é o contexto imediato; consideradas em sentido amplo incluem o contexto sócio-histórico e ideológico. A memória neste caso é tratada como interdiscurso porque já foi pensada ou falada antes. Segundo Orlandi (2012, p.31) “é o que chamamos de memória discursiva: o saber discursivo que torna possível todo dizer e que retorna sob a forma do pre-construído, o já-dito que está na base do dizível, sustentando cada tomada da palavra".

Orlandi explica que o dizer não é propriedade particular, as palavras não são só nossas, elas significam pela história e pela língua, algo que não se aprende e não se ensina, mas que produz seus efeitos. "Escolhemos as palavras porque já estamos filiados a uma rede de sentidos sem mesmo percebermos. Essa escolha não é consciente, vai depender da história e segundo Orlandi do acaso". Todavia nossa escolha está relacionada com a relação com a língua e a história, por nossa experiência de mundo, através da ideologia (idem, 2012, p.34). 


\section{Formação Discursiva}

O conceito de formação discursiva vem de Foucault, de sua obra Arqueologia do Saber, da qual Pêcheux usou a expressão formação discursiva, para um emprego específico nos estudos do discurso. Foucault (2005, p.43) explica que a formação discursiva acontece quando:

[...] se puder descrever, entre um certo número de enunciados, semelhante sistema de dispersão, e no caso em que entre os objetos, os tipos de enunciação, os conceitos, as escolhas temáticas, se puder definir uma regularidade (uma ordem, correlações, posições e funcionamentos, transformações), diremos, por convenção, que se trata de uma formação discursiva.

A noção de formação discursiva, ainda que polêmica é básica na $\mathrm{AD}$, pois permite compreender o processo de produção dos sentidos, a sua relação com a ideologia e também dá ao analista a possibilidade de esclarecer regularidades no funcionamento do discurso.

Para Brandão (2002, p.90):

A formação discursiva é um conjunto de enunciados marcados pelas mesmas regularidades, pelas mesmas regras de formação. A formação discursiva se define pela sua relação com a formação ideológica, isto é, os textos que fazem parte de uma formação discursiva remetem a uma mesma formação ideológica. A formação discursiva determina "o que pode e deve ser dito" a partir de um lugar social historicamente determinado. Um mesmo texto pode aparecer em formações discursivas diferentes, acarretando com isso, variações de sentido.

Sobre formação discursiva, Orlandi (2012, p.42-43) esclarece que as palavras mudam de sentido segundo as posições daqueles que as empregam, ou seja, tudo depende das formações ideológicas nas quais essas posições se inscrevem. O que pode e deve ser dito será definido "a partir de uma posição dada em uma conjuntura sóciohistórica dada" (idem, 2012, p.43). O discurso se constitui em seus sentidos porque aquilo que o sujeito diz se inscreve em uma formação discursiva e não outra para ter um sentido e não outro. Desta forma, as palavras não têm um sentido nelas mesmas, estão inseridas nas formações discursivas em que se inscrevem. Portanto, o discurso não é fechado em si mesmo e nem é do domínio exclusivo do locutor: "aquilo que se diz significa em relação ao que não se diz, ao lugar social do qual se diz, para quem se diz, 
em relação a outros discursos" (idem, 2006, p.83). Isso tudo que se articula pode ser analisado na relação entre as formações discursivas e a formação ideológica dominante.

\section{Formação Ideológica}

Brandão (2002, p.90) explica que "a formação ideológica é constituída por um conjunto complexo de atitudes e representações que não são nem individuais, nem universais, mas dizem respeito às posições de classe em conflitos umas com as outras". Cada formação ideológica pode compreender várias formações discursivas interligadas.

Pinto (1999) explica que quando nos assumimos como emissores ou coemissores de uma situação de comunicação, desde "os primeiros momentos em que na primeira infância acordamos para a comunicação e a linguagem, estamos entrando no amplo mundo das representações (conhecimentos e crenças), das relações e identidades sociais", e aceitamos alguma forma de controle social. Aprendemos a ser o que somos por meio das regras e convenções aos discursos que dominamos, as quais não podemos ignorar e que só podemos alterar em situações de mudança social, mesmo que pensemos ser os senhores absolutos da nossa vontade. Entramos nesse mundo de aparências, no mundo do ideológico e do poder, que é o mundo da linguagem (PINTO, 1999, p. 40).

Não há como negar que o ideológico está presente no texto pelas marcas ou traços que estas "regras formais de geração de sentidos deixam na superfície textual e que o analista de discursos procura encontrar e interpretar"(idem, 1999, p.41). Uma parte do ideológico também transparece num texto sob a forma de preconstruídos, que "são inferências e pressuposições que o coemissor deve fazer para suprir as lacunas e dar coerência à interpretação que faz, interligando entre si as frases e partes do texto e ligando-o a um mundo" (idem, 1999, p.41). Na verdade este intertexto consensual, assim como as regras formais de investimento, contribuem para sustentar, de modo direto ou indireto, relações de poder desiguais, relativas às diferenças sociais entre os participantes do evento. Essas disputas criam relações de dominância entre os discursos reconhecidos como hegemônicos e os discursos subordinados, favorecendo a naturalização ou reificação (como coisificação das relações sociais, conforme o marxismo, quando tudo passa a contar como mercadoria ou valor de troca) dos primeiros discursos (PINTO, 1999, p.41). 
Em Ideologia e Aparelhos Ideológicos do Estado (1974), Althusser afirma que, para manter sua dominação, "a classe dominante gera mecanismos de perpetuação ou de reprodução das condições materiais, ideológicas e políticas de exploração". É aí que entra o papel do Estado, que através de aparelhos repressores - compreendendo o governo, a administração, o Exército, a política, os tribunais, as prisões etc - e aparelhos ideológicos, compreendendo "religião, a escola, a família, o Direito, a política, o sindicato, intervém ou pela repressão ou pela ideologia", tentando forçar a classe dominada a submeter-se às relações e condições de exploração (ALTHUSSER, 1974, p.43-44).

Segundo Brandão (2002, p.21-24), Althusser formula três hipóteses para explicar a sua ideologia em geral.

Primeira: "a ideologia representa a relação imaginária de indivíduos com suas reais condições de existência". Com esta tese, Althusser se opõe à concepção simplista de ideologia como representação mecânica da realidade; para ele, a ideologia é a maneira pela qual os homens vivem a sua relação com as condições reais de existência, e esta relação é necessariamente imaginária. "O imaginário é o modo através do qual o homem atua, relaciona-se com as condições reais de vida, sendo essas relações imaginárias, isto é, representadas simbolicamente, abstratamente, supõem um distanciamento da realidade". E esse distanciamento pode ser o caminho para a alienação das condições de existência do homem.

Segunda: "A ideologia tem uma existência porque existe sempre num aparelho e na sua prática ou suas práticas". Para explicar sua tese, Althusser parte da colocação feita por uma corrente idealista que reduz a ideologia a ideias dotadas por definição de existência espiritual; em outras palavras, o comportamento material de um sujeito dotado de uma consciência em que forma livremente as ideias em que crê. A existência da ideologia é, portanto, material porque as relações vividas envolvem a participação individual em determinadas práticas e rituais no interior de aparelhos ideológicos concretos. Isso leva Althusser a concluir que a prática só existe numa ideologia e através de uma ideologia.

Terceira: "A ideologia interpreta indivíduos como sujeitos". Toda ideologia tem por função constituir indivíduos concretos em sujeitos. Nesse processo de constituição, a interpelação e o (re) conhecimento exercem papel importante no 
funcionamento de toda ideologia. É através desses mecanismos que a ideologia, funcionando nos rituais materiais da vida cotidiana, opera a transformação dos indivíduos em sujeitos. O reconhecimento se dá no momento em que o sujeito se insere, a si mesmo e a suas ações, em práticas reguladas pelos aparelhos ideológicos. Será somente através do sujeito e no sujeito que a existência da ideologia será possível (BRANDÃO, 2002, p.21-24).

Há muito mais o que falar sobre condição de produção do discurso, formação discursiva e formação ideológica, considerados fundamentais para o estudo da linguagem, mas para os limites deste trabalho ficaremos com estas colocações, guardando alguns princípios básicos que serão fundamentais para nos debruçarmos na análise, propriamente dita.

Nosso objetivo é investigar como se dá a construção social do papel da mulher no discurso religioso e analisar a sua representação no programa Show da Fé. Estas condições de produção já darão margem a recortes discursivos pertinentes ao lugar de quem fala (missionário), ou seja, fazem parte da identidade do discurso acessado pelo sujeito, trazendo sentidos pré-construídos que figuram na memória do dizer da sociedade. A interpretação deverá ser feita sempre entre o interdiscurso e o intradiscurso chegando às posições representadas pelos sujeitos através das marcas linguísticas.

$\mathrm{O}$ quadro de formações discursivas sobre o casamento se mostrou o mais recorrente na seleção das cartas. As cartas com este perfil diziam respeito a relacionamentos desfeitos, traições, violência doméstica e simbólica, separações, divórcios, ciúmes no relacionamento etc. Por isso, elegemos duas cartas que trouxeram as seguintes formações discursivas:

\section{Quadro de Formações Discursivas - Tema Casamento}

A seleção das cartas mostra a principal motivação que levou as mulheres a escreverem: o casamento. A Bíblia diz: "O que Deus uniu, jamais separe o homem" (MARCOS,10-9). É com base neste versículo bíblico que muitas mulheres se veem envolvidas em um casamento falido e desprovido de proteção. Porém, olhando para o texto o que temos é a interpretação da vontade de Deus expressa, é Ele quem faz isso acontecer, exatamente porque é Ele quem quer que assim seja. É Deus quem une. E aquilo que é por Ele unido, não pode ser por nós, a bel-prazer, separado. "A noção de 
família indissolúvel é o discurso mais frequente nas celebrações de casamento cristãos, e o até que a morte os separe é o slogan mais famoso" (SOUZA, 2009, p.18).

A questão que permeia esta discussão é: como se preservar em um casamento na esperança de uma transformação divina? Esta é a pergunta chave, é isso que as mulheres desejam saber, é em busca de uma resposta às suas aflições que elas escrevem. A mulher cristã. Que mulher é essa? Como ela se reconhece?

O primeiro enfoque deve ser dado à postura que a mulher ocupa dentro do seu lar e a forma como ela se vê responsável por manter uma estrutura familiar sólida, conforme Machado (2005, p.2) "já as mulheres, associam suas escolhas religiosas com as desavenças familiares e as necessidades materiais e espirituais do grupo doméstico, ou seja, as mulheres se sentem responsáveis e guardiãs das almas de todos que integram a família". Nas cartas escritas, se nota certa melancolia, um sentimento de fragilidade, de insegurança, de alguém que precisa ser ouvida, ajudada e acolhida. Elas buscam a justiça de Deus que dê sentido ao seu sofrimento e justifique a sua permanência em um casamento falido. Mas da mesma forma que elas precisam da bênção para casar, precisam da bênção também para se separar. Essa legitimação religiosa é o ponto de apoio destas mulheres, só isso justificaria as perguntas: o que eu faço, missionário? E os apelos: por favor, me ajude, ore por mim e pela minha família.

\section{Formação Discursiva 1 (FD1) "A Mulher Cristã":}

Programa 21 agosto 2011 (domingo) - 18h IN 1:00:54 OUT 1:06:00 (Anexo I) Mulher diz que não é casada, mora com um companheiro e só tem derrotas.

$\mathrm{Na}$ leitura das cartas são recorrentes algumas palavras ou expressões, por exemplo: não obedecer à Palavra de Deus, não ser fiel aos mandamentos de Deus, o diabo, o pecado, como podemos observar nos trecho que seguem: “[...] Esse negócio de casamento é uma problemática tremenda, quando a pessoa não obedece à Palavra de Deus".[...] Eu pra dar um conselho à senhora teria que ter mais detalhes, mas um outro pastor pode fazer isso e orientar dentro da Palavra do Senhor Deus".[...] não o Francisco tem que deixar a Maria, a Maria é muito feia pra ele, tem que pegar aquela que é novinha, bonitinha, a Maria com aquele velhão, para com isso, né? Quer dizer, fica pondo minhoca na cabeça e o Francisco e Maria, as outras Franciscas, os outros Franciscos e Marias são fracos de mente e começam desejar. E o demônio põe tudo e 
encaixa. As coisas começam anos ali” (Anexo I). A AD mostra que não há nenhum discurso transparente, a finalidade da grande maioria dos discursos, principalmente daqueles carregados de força persuasiva, é fazer com que os interlocutores creiam no que é veiculado e executem ações. No caso do discurso religioso crer e executar são necessários, pois ele é, ao mesmo tempo, de ordem cognitiva e prática, isso quer dizer que em primeiro lugar é preciso garantir que os fiéis creiam no que é dito, para depois o fiel agir. Aqui entra em jogo um fator de extrema importância que é a relação de confiança firmada entre os interlocutores. Tendo clara a confiança que estas mulheres depositam no enunciador, tudo o que for dito daqui para a frente deve ser encarado como verdade e, principalmente, como mandamento de Deus.

A fé será a base da nossa análise, fé depositada nas palavras, no homem que a profere, na certeza que dali sairá a vontade de Deus para a vida delas. Em relacionamentos tão descompensados dizer que "[...] separação segundo a Bíblia, só pode haver em caso de adultério. E coitado do responsável pelo adultério. Essa pessoa vai pagar caro, por não ter mantido o voto" (Anexo I), é sugerir que tudo se deve suportar, que a mulher sábia sabe como lidar com as adversidades e principalmente sabe levar a sua família para a fé. O enunciador fala com base nas escrituras que dizem: "Eu, porém, vos digo que qualquer que repudiar sua mulher, a não ser por causa de prostituição, faz que ela cometa adultério, e qualquer que casar com a repudiada comete adultério" (MATEUS 5-32).

Este é um dos assuntos mais polêmicos no meio cristão, pois há muitos casos de violência, traição e abandono, que são de forma sutil tratados pelos líderes religiosos, principalmente quando o meio usado para isso é um canal de televisão. Estudiosos já fizeram muitas críticas sobre as igrejas midiáticas e afirmam: "Eles continuamente pecam contra o segundo mandamento, que é usar o santo nome de Deus em vão e apresentam um cristianismo que é um pequeno Lexotan para acalmar as pessoas" (BOFF, 2011, on-line).

Nesse contexto, a mídia passa a afetar os modos através dos quais as instituições agem e também as relações entre os sujeitos. Por isso, surge a sociedade em processo de midiatização. 


\section{Formação Discursiva 2 (FD2) "A ambiguidade: Mulher Cristã x Mulher Contemporânea":}

Programa 18 setembro 2011 - (sábado) 14h IN 1:10:20 OUT 1:12:37 (anexo II) Mulher foi transferida para outra cidade, está longe do marido. Sobre relacionamento intimo.

Até agora falamos das mulheres cristãs, aquelas que frequentam igrejas, que são submissas aos maridos, que ouvem o pastor e se fortalecem nos ensinamentos oriundos do seu discurso. Mas essas mulheres são vistas com ambiguidade, pois se retomarmos àquilo que se sabe sobre a mulher do passado, ao mesmo tempo em que elas são vistas como frágeis e vítimas, são reconhecidas também como perigosas e pecadoras. Estas características trazem à memória duas mulheres da Bíblia: Eva e Maria. A primeira pecou, a segunda foi santa e obediente. Esta última é o modelo que deve ser seguido por toda mulher "evangélica".

No caso, tudo o que já foi dito sobre a mulher evangélica, seu jeito de ser, sua busca, está, de certo modo, significando aqui, é o que Orlandi (2012, p.31) chama de interdiscurso. E há nas cartas esta busca, este desejo por desempenhar um papel cujas funções foram delegadas por Deus, como a tarefa de ser boa mãe e esposa. O discurso religioso acentua a representação da mulher como sofredora e submissa e cria a sua identidade, inclusive reforçando construções discursivas como "o homem é o cabeça", por exemplo. "A afirmação sociocultural da masculinidade passa pelo exercício do poder do homem sobre a mulher e os filhos, e a religião tem colaborado com a reprodução dessa representação social da masculinidade" (SOUZA, 2004, on-line, p.6).

Não é nenhuma novidade dizer que as mulheres estão buscando cada vez mais seu "lugar ao sol", ou seja, desejam aperfeiçoamento profissional, rumo à independência financeira e resgate da autoestima. Esta escolha pode ou não vir associada à família, ligada às oportunidades que se apresentam e das quais as mulheres contemporâneas não estão dispostas a abrir mão, mas se sentem culpadas por fazerem a escolha pelo trabalho. Há um conflito interno muito grande.

Uma das cartas do programa do dia 18 setembro 2011 - (sábado, anexo II) nos remete à seguinte situação: Desempregada há cinco anos, a telespectadora passou por muitos problemas, após passar em um concurso público, achou que tudo ficaria bem, mas a distância do trabalho a impede de ficar perto da família. "Esse negócio de ficar longe da família, faz mal mesmo!” Aqui entra o saber discursivo, o interdiscurso como 
resposta, conceitos pré-construídos, formulações feitas e já esquecidas que determinam o que dizemos. Na carta, ela fala que ficar longe da família faz muito mal, não se refere ao marido, especificamente, mas a questão pontual que gerou a resposta seguiu em torno do distanciamento que ela tem do marido, do fato que eles estão, por conta dessa decisão, vivendo e dormindo separados, e isso não é bom, é a "brecha que satanás precisa para agir". Utilizando o intertexto, parafraseando passagens bíblicas, o missionário responde:

A Bíblia fala de uma maneira muito clara. O marido e a mulher têm que viver sempre em comunhão conjugal e se eles se separarem pra oração, tem que ser por um breve período, que não há necessidade de separar, mas vamos dizer que sentiu no coração, vamos dormir separado por breve período, terminou; volte correndo (Anexo II).

Notamos um desvio de sentido, uma questão relacionada à família, foi transferida para o marido em evidência, e posteriormente, aos jovens: "E todo mundo que é solteiro, trata de obedecer à Palavra de Deus." Não houve uma relação de coerência entre pergunta e resposta. O que tem a ver com os jovens, aqueles que são solteiros decidirem-se pelo casamento se a questão apontada não é esta? Há um deslize na interpretação, portanto, sob o viés da $\mathrm{AD}$, não há sentidos fixos que devem ser extraídos do discurso, sendo o discurso efeito de sentidos, este deve ser construído a partir da atividade do sujeito leitor, que é sempre histórico e marcado pela ideologia (ORLANDI, 2012).

Orlandi (2012, p.79) explica que o "processo de produção dos sentidos está necessariamente sujeito ao deslize, havendo sempre um 'outro' possível que o constitua". Este desvio pode estar relacionado ao fato que a mulher a partir do momento em que decide se casar deve ter claro que esta união não deve desfazer-se em hipótese alguma, e isso implica abrir mão de escolhas pessoais em favor da família, como afirmou o enunciador “[...] é preferível até deixar o emprego, arranjar um outro que ganhe até menos, mas que não destrua a sua felicidade. Marido e mulher tem que ficar juntos" (anexo II). Há coerção no uso das palavras, a saber: "mas que não destrua a sua felicidade". Não há saída, escolher pelo emprego e pela estabilidade financeira é abrir mão da felicidade. É o que deve ser feito para evitar a dor ou outras consequências negativas, porque isso terá um efeito imediato sobre a vida do casal. Todavia o pronome 
empregado não é no plural nosso (casal) e sim "sua felicidade". Sua escolha, sua felicidade, sendo a mulher responsável por essa decisão. Retomando conceitos da questão de gênero, muito oportuno neste exemplo relacionado ao casamento.

A concepção do casamento como união para a vida toda, haja o que houver, a noção de uma hierarquia familiar em que o homem manda e a mulher obedece, a socialização dos homens para a dominação e das mulheres para a sujeição, são alguns dos muitos elementos que compõem a complicada equação da questão de gênero em nossa sociedade e que extrapola as paredes da casa (SOUZA, 2009, p.21).

Este processo discursivo não é novo, a cultura que produz e naturaliza as hierarquias de gênero já existe desde o período colonial. Retomemos o enunciado: “[...] é preferível até deixar o emprego", esta fala nos remete ao tempo em que as mulheres não podiam sequer frequentar escolas, ficando excluídas do âmbito social. Em contrapartida, eram treinadas para a vida doméstica, na qual o casamento, a administração da casa e os afazeres domésticos eram seus maiores deveres. Se ela deixar o emprego, deixará também a sua independência, a sua carreira, talvez deixará de sustentar a família. Em Tito 2:3-5, Paulo nos dá instruções sobre como uma jovem esposa deve ser treinada pelas mulheres mais velhas:

[...] As mulheres idosas, semelhantemente, que sejam sérias no seu viver, como convém a santas, não caluniadoras, não dadas a muito vinho, mestras no bem; para que ensinem as mulheres novas a serem prudentes, a amarem seus maridos, a amarem seus filhos, A serem moderadas, castas, boas donas de casa, sujeitas a seus maridos, a fim de que a palavra de Deus não seja blasfemada (TITO 2-3) .

Nessa passagem, a Bíblia é clara no que se refere às crianças, elas são a responsabilidade principal da jovem esposa. O dever das mulheres mais velhas é de ensinar as mulheres jovens a viver uma vida que glorifique a Deus. Mantendo estas responsabilidades em mente, o tempo da mulher mais idosa pode ser gasto de acordo com a direção do Senhor e de acordo com o seu próprio critério (TITO 2-5).

\footnotetext{
${ }^{3}$ Para esta citação utilizamos a Bíblia Almeida Revista e Corrigida que é a versão mais original e conservadora em sentido de linguagem e estilo da tradução da Bíblia de João Ferreira de Almeida, ainda em uso nas principais Igrejas Cristãs evangélicas no Brasil, nos momentos de culto, pregação, estudo e aconselhamento pastoral, por ser fiel ao Texto Sagrado desenvolvido e produzido pelo próprio $\underline{\text { João }}$ Ferreira de Almeida.
} 
Essas são algumas reflexões que supostamente possam existir, no entanto a realidade analisada no discurso apresentado é: esta mulher na qualidade de mãe e esposa, conseguindo um emprego longe de casa, transgrediu as regras, ela rompeu com o sistema de significados que deveriam fazer dela uma esposa submissa e obediente.

\section{Considerações Finais}

Tudo aquilo que valorizamos nos causa interesse, queremos conhecer, entender as questões que permeiam o nosso jeito de ser e as nossas escolhas; sejam elas afetivas, profissionais ou religiosas. Então, não é nossa intenção chegar a uma única conclusão, o que se revela impossível dado o processo observado, o que fazemos é uma escolha sobre as variadas possibilidades interpretativas.

Estamos refletindo sobre este processo entre mídia e religião, da religião se apropriando do espaço midiático como forma de disseminar doutrinas. As igrejas que se apropriaram deste novo jeito de pregar o evangelho são as chamadas igrejas pentecostais independentes ou neopentecostais, estas já nasceram na era das mídias, diferentemente das igrejas tradicionais, que não viam com bons olhos a presença da mídia.

Por ser um tema em estado de transformação, vivendo uma espécie de metamorfose, o campo religioso tem sido recentemente objeto de vários estudos e pesquisas. Neste trabalho teórico-empírico sobre a representação da mulher cristã nas mídias, muitas outras questões poderiam ter sido levantadas, afinal, estamos falando de um ser de muitas faces, muitas vontades, desejos, sonhos e necessidades. Pensar o discurso religioso midiático com ênfase no lugar que a mulher ocupa na vida cristã nos apontou muitos desafios para a reflexão e futuras pesquisas, perceber que a maneira como a pessoa se reconhece, faz toda a diferença nas suas atitudes e decisões, ou seja, reconhecendo-se fracas e doentes, condicionadas a uma vida de miséria e violência, se perpetua tanto uma relação de dependência com o outro (sendo esta figura o pai, o marido ou o próprio filho) quanto a falta de motivação pela vida. Concluímos também que as igrejas midiáticas estão mais interessadas no mercado, trabalhando de forma pesada para que seus produtos sejam vendidos, e isso inclui os sermões e as pregações, considerando-se o contexto atual, marcado pela liquidez das relações e das identidades, numa sociedade altamente consumista (inclusive no contexto religioso), a tendência à 
espetacularização da vida, dos milagres e da fé. Os movimentos atuais - no caso o da IIGD - além de diminuírem e estereotiparem a imagem da mulher constroem uma forma de "ver Deus", mais calcada nos imperativos de uma dinâmica capitalista neoliberal e de reprodução da cultura patriarcal baseada nos princípios da aceitação/resignação, da submissão, da renúncia/concessão e da responsabilidade/culpabilidade que caracterizam o lugar das mulheres no imaginário religioso, mais fortemente no pentecostalismo.

\section{Referenciais}

ALMEIDA, J.F. (trad.). Bíblia Sagrada. São Paulo: Sociedade Bíblica do Brasil, 1993. ALTHUSSER, L. Ideologia e aparelhos ideológicos de estado. Trad. Joaquim José de Moura Ramos. Título original: Ideologie et Apareils Ideologiques D‘État. Lisboa: Editorial Presença, Livraria Martins Fontes, 1974, 120p.

BOFF, Leonardo. Igrejas Midiáticas são pecadoras. 2011. Disponível em: $<$ http://www1.folha.uol.com.br/multimidia/videocasts/980822-igrejas-midiaticas-saopecadoras-diz-teologo-leonardo-boff.shtml>. Acesso em: 31 março 2013.

BORELLI, Viviane. Igrejas Midiáticas. Entrevista concedida ao Instituto Humanitas Unisinos, RS. Disponível em: < http://www.ihu.unisinos.br/entrevistas/500446-igrejasmidiaticas-o-objetivo-e-garantir-o-contato-com-o-fiel-e-a-permanencia-de-sua-marcajunto-a-ele-entrevista-especial-com-viviane-borelli>, 18 set.2011.

BRANDÃO, Helena H. Nagamine. Introdução à análise do discurso. 8 ed. Campinas, SP: Unicamp, 2002a, 2004b. 95p.

CUNHA, Magali do Nascimento Cunha. A Explosão Gospel. Rio de Janeiro: Muad X: Instituto Mysterium, 2007.

CUNHA, Magali do Nascimento, et alli...Discurso Religioso, hegemonia pentecostal e mídia no Brasil: A presença televisiva do pastor do R.R.Soares: um estudo de caso. Revista Caminhando, v.13, n.21, p.87-96, jan-mai, 2008. Disponível em:< https://www.metodista.br/revistas/revistas-ims/index.php/CA/article/viewArticle/1218>. Acesso em: 30 maio 2013.

FOUCAULT, Michel. A arqueologia do saber. Trad. Luiz Felipe Baeta Neves. 7.ed. Rio de Janeiro: Forense Universitária, 2005, 236p.

MACHADO, Maria das Dores Campos. Representações e relações de gênero nos grupos pentecostais. Revista Estudos Feministas. vol.13, n.2. Florianópolis maio/agosto, 2005.

MARIANO, Ricardo. Expansão pentecostal no Brasil: o caso da Igreja Universal. Estudos Avançados 18 (52), 2004, p. 121-138. Disponível em: 〈〉. Acesso em: 13 set. 2010.

MORAES, Gerson Leite de. Idade Mídia Evangélica no Brasil. São Paulo: Fonte Editorial, 2010, 248p.

NATELINHA.COM. - Show da Féll, de R.R. Soares, é a quinta maior audiência da Band. do dia 2 agosto 2012. Disponível em: <http://natelinha.ne10.uol.com.br/noticias/2012/08/02/show-da-fe-de-rr-soares-e-aquinta-maior-audiencia-da-band--51971.php>. Acesso em: 31 maio 2013.

NOTÍCIA.UOL. Para renovar com pastor, Band quer mais de R 10 milhões por mês, feita pelo colunista Ricardo Feltrin, dia 19/03/2013, às13h13. Disponível em: 
http://noticias.uol.com.br/ooops/ultimas-noticias/2013/03/19/para-renovar-com-pastorband-quer-mais-de-r-10-milhoes-por-mes.htm>. Acesso em: 31 maio 2013.

ORLANDI, Eni Puccinelli. Análise de discursos: princípios e procedimentos. $10^{\circ}$ ed.Campinas, SP. Pontes Editores, 2012, 100p.

A Linguagem e seu Funcionamento: as formas do discurso. 4.ed. Campinas: SP: Pontes Editores, 2006, 276p.

PINTO, Milton José. Comunicação e Discurso: introdução à análise de discursos. São Paulo: Hacker Editores, 1999.105p.

SOUZA, Priscila Vieira. Implicações e possibilidades da investigação histórica. Doutoranda no PPGCOM da Universidade Federal do Rio de Janeiro -UFRJ, Rio de Janeiro. Disponível em: <http://www2.metodista.br/unesco/1_Eclesiocom\%202012/Trabalhos/14.M\%C3\%ADdi a\%20e\%20Religi\%C3\%A3o\%20no\%20Brasil_Priscila\%20Souza.pdf $>$. Acesso em: 4 dez 2012

SOUZA, Sandra Duarte de; LEMOS, Carolina Teles. A Casa, as mulheres e a Igreja: relação de Gênero e Religião no contexto familiar. São Paulo: Fonte Editorial, 2009. $180 \mathrm{p}$.

SOUZA, Sandra Duarte de. Revista Mandrágora: gênero e religião nos estudos feministas. Revista Estudos Feministas. v.12. Florianópolis set/dez, 2004. Disponível em:< http://www.scielo.br/scielo.php?script=sci_arttext\&pid=S0104026X2004000300014>. Acesso em: 15 maio 2012. 


\section{ANEXOS}

\section{ANEXO I}

Programa 21 agosto 2011 (domingo) - 18h IN 1:00:54 OUT 1:06:00

Mulher diz que não é casada, mora com um companheiro e só tem derrotas.

\section{CARTA}

Missionário,

Tive um casamento falido e resolvi me divorciar. Há seis anos, estou morando com um companheiro, mas não acertamos nossa situação. Eu sei que isso não está certo e que Deus não se agrada da minha decisão. Por conta disso, não recebo as bênçãos que ele tem reservado para nós. Só tenho derrotas na vida, uma atrás da outra. Quero muito ser feliz e ter paz, mas não consigo. O senhor acha que Deus está me punindo por que eu não fui fiel? Por favor, Missionário, me oriente. O que devo fazer para ter alegria na vida?

\section{RESPOSTA}

Esse negócio de casamento é uma problemática tremenda, quando a pessoa não obedece à Palavra de Deus. Separação segundo a Bíblia, só pode haver em caso de adultério. E coitado do responsável pelo adultério. Essa pessoa vai pagar caro, por não ter mantido o voto. Esse negócio dessas novelas enjoadas, esses filmes enjoados, por isso que eu faço sempre campanha da nossa TV aqui. Elas corrompem, as pessoas perdem a noção do valor da fidelidade. Porque eles colocam ali que não tem jeito, põe um cara com cara de alegre, feliz e tudo e depois as pessoas embarcam em barcos furados. Eu pra dar um conselho à senhora teria que ter mais detalhes, mas um outro pastor pode fazer isso e orientar dentro da Palavra do Senhor Deus. Agora, vamos dizer assim, se tudo ocorreu antes da senhora conhecer a verdade, aí fica mais fácil, mas se já conhecia a verdade a coisa se complica mais. Nós temos responsabilidade pra andar na luz, porque nós somos luz no Senhor. Mas o Senhor Deus não anda punindo ninguém, o Senhor Deus anda acertando situações. Conversa com ele direitinho, procura um pastor, mais abra o coração, não omita detalhe algum, chato é quando a pessoa omite detalhes porque a gente não pode aconselhar direitinho. E ore a Deus. Deus é poderoso pra lhe levantar, Deus é poderoso pra lhe dar saída, o Senhor Deus está na época de acertar as coisas. E quem, olha, quem está sendo tentado e bateu uma paixão no seu coração, meu 
irmãozinho, minha irmãzinha, dá uns passos pra trás e aí fuja desse negócio, porque se a queda vier, vem tristeza, vem dor, vem tudo e enquanto você não pecou, não pecou, então é fácil. Depois que pecar fica aquela marca, aquela ferida, aquela cicatriz, e nós precisamos estar bem com o nosso Deus é isso que ele quer. Eu falei aqui dessas coisas que fazem porque são uns irresponsáveis, eles bolam uma situação que a maioria é tudo mentira. O mesmo que aconteceu com eles e desenham ali, escrevem, a gente que tem uma capacidade pra escrever, pode escrever irresponsavelmente uma porção de coisas e depois, e põe gente famosa, bonita, bem dotada de um físico maravilhoso e talentosa no representar e as pessoas ficam achando que é verdade, até torce, não o Francisco tem que deixar a Maria, a Maria é muito feia pra ele, tem que pegar aquela que é novinha, bonitinha, a Maria com aquele velhão, para com isso, né? Quer dizer, fica pondo minhoca na cabeça e o Francisco e Maria, as outras Franciscas, os outros Franciscos e Marias são fracos de mente e começam desejar. E o demônio põe tudo e encaixa. As coisas começam anos ali. Um dia o médico me disse que quando o câncer aparece, já tá trabalhando a cinco anos no corpo da pessoa. Quando o pecado aparece já tá trabalhando, é uma coincidência no trabalho, é uma conversa dentro de casa, é uma chateação e quando vê acontece. Aí depois é só dor, só sofrimento. Meu irmão a única maneira, a única medicina que cura todo o mau, é a palavra de Deus. Porque ela é preventiva, e também ela cura depois, mas o bom é quando você pega a palavra, teme a palavra de Deus, você evita qualquer coisa. Solteiros, não entrem em fornicação, e se sentiu de Deus que não dá certo, não importa se a pessoa é bonita. Você não vai casar com a pessoa pra ficar dando show pros outros, você precisa de uma pessoa que realmente seja de bom caráter, que tema a Deus e que lhe complete. Que você se agrada da pessoa. Não fique indo por questão de Hollywood que fala aquelas coisas bonitas, põe aqueles músicos bonitão, atrás tem uma música e a pessoa vai. Paulo disse que as mulheres mais velhas, deveriam ensinar as mais novas a amar seus maridos. Então até o amor se aprende. Não, não, mas esse casamento não foi no céu porque eu não tô realizada. E vai pra mão de outro, de outra e não tá, não tá e não tá e se perde todo. 


\section{ANEXO II}

\section{Programa 18 setembro 2011 - (domingo) 14h IN 1:10:20 OUT 1:12:37}

Mulher foi transferida para outra cidade, está longe do marido. Sobre relacionamento íntimo.

CARTA

Missionário,

Sou cristã, casada e passo por uma fase complicada. Fiquei desempregada por cinco anos, até que fui chamada em um concurso público. Pensei então, que meus problemas seriam resolvidos. Mas, por conta da distância do meu trabalho, fico muito tempo longe da minha família e isso me faz muito mal. Por favor, missionário, preciso de uma orientação!

\section{RESPOSTA}

Esse negócio de ficar longe da família, faz mal mesmo! A pessoa que foi transferida pra outra cidade, deve levar a família, ou então, arranjar um jeito ou outro trabalho. Casados não podem ficar separados. A Bíblia fala de uma maneira muito clara. O marido e a mulher têm que viver sempre em comunhão conjugal e se eles se separarem pra oração, tem que ser por um breve período, que não há necessidade de separar, mas vamos dizer que sentiu no coração, vamos dormir separado por breve período, terminou volte correndo. Diz o Espírito Santo, para que satanás não vos tente. Ninguém é durão o suficiente, para não cair na cilada do diabo. Então, a pessoa tem que ter juízo. E todo mundo que é solteiro, trata de obedecer à Palavra de Deus. Ela diz: o homem deixará pai e mãe, unir-se-à a mulher, e serão dois numa só carne. Tem que obedecer, não é bom que o homem fique só. Quando fala o homem, também tá falando a mulher e pare desse negócio de ficar com ideia de Hollywood na cabeça, que vai aparecer aquela pessoa, quer dizer, é, vai aparecer aquela que Deus marcou pra você. Aquela que você sentiu no coração. E para com essa bobeira, de ficar adiando, adiando, você tá perdendo é tempo na vida! Então, aproveita, tome posse da bênção e seja uma pessoa bem estruturada, alicerçada na palavra, uma pessoa que vai dar alegrias ao Senhor Deus! Então verifique bem esse negócio aí, ore a Deus. É preferível até deixar o emprego, arranjar um outro que ganhe até menos, mas que não destrua a sua felicidade. Marido e mulher têm que 
ficar juntos. A vida deles é em comum, e não pode nem em pensamento ter uma terceira pessoa.

Recebido: $25 / 02 / 2014$

Received: 02/25/2014

Aprovado: $19 / 07 / 2014$

Approved: 07/19/2014 